\title{
Anti-ethylene Treatments for Potted Christmas Cactus-Efficacy of Inhibitors of Ethylene Action and Biosynthesis
}

\author{
Margrethe Serek ${ }^{1}$ and Michael S. Reid \\ Department of Environmental Horticulture, University of California, Davis, \\ CA 95616
}

\begin{abstract}
Additional index words. Schlumbergera truncata, aminoethoxyvinylglycine, silver thiosulfate
\end{abstract}

\begin{abstract}
Spraying flowering plants of Schlumbergera truncata (Haw.) 'White Christmas' with aminoethoxyvinylglycine (AVG), an inhibitor of ethylene biosynthesis, did not prevent the rapid loss of flower buds caused by exposure to $1 \mu \mathrm{l}$ of ethylene/liter. Treatment with the silver thiosulfate anionic complex (STS) strongly inhibited such effects. The rate of bud drop in ethylene-free air (interior environment room) was somewhat reduced by AVG treatment, although total display life of treated plants was not significantly different from that of the controls. STS treatment reduced the rate of bud drop, and increased display life by $20 \%$.
\end{abstract}

The display life of many flowering potted plants is limited by the loss of flowers, buds, or leaves, caused by ethylene in the air or by stresses that induce ethylene responses (Fjeld and Moe, 1985; Reid, 1985; Reid and Wu, 1992). These effects have been overcome by pretreating plants with silver thiosulfate (STS), an inhibitor of ethylene action (Veen and van de Geijn, 1978). STS is now commonly used commercially to improve the display life of potted flowering plants (Cameron and Reid, 198 1; Serek, 1993; Veen, 1983). Plants are normally sprayed, in the greenhouse, with concentrations of STS between 0.1 and $2 \mathrm{~mm}$ when the buds start to show color (Cameron and Reid, 1981; Fjeld and Moe, 1985; Nowak and Rudnicki, 1990; Serek, 1993). The use of a heavy metal salt for horticultural purposes inevitably raises environmental concerns, as evidenced by the ban on STS spraying in Holland, where environmental contamination is minimized by wiping the leaves with a soft roller impregnated with STS.

Because of these environmental concerns relating to the use of STS in horticulture,

Received for publication 26 Mar. 1993. Accepted for publication 19 July 1993. We thank F. Jackson Hills, Peggy Hale, and Carol Adams for advice on dataanalysis; Linda Dodge and Mercedes Fernandez Sanchez for technical assistance; and Tad Nakazawa (Bay City Flower Co.) for kindly supplying the plants. The experiments were supported by a grant from the Danish Agricultural and Veterinary Research Council (grant no. 13-4549) and supplementary grants from the Foundation of Hofmansgave, the Foundation of Ib Henriksen, and the Carlsberg Foundation (MS). The cost of publishing this paper was defrayed in part by the payment of page charges. Under postal regulations, this paper therefore must hereby be marked advertisement solely to indicate this fact.

'On leave from The Royal Veterinary and Agriculture Univ., Dept. of Agricultural Sciences, Section for Horticulture, Rolighedsvej 23, 1958 Frederiksberg C, Denmark. researchers have been seeking alternative tools to control the effects of ethylene in the display life of potted plants (Dostal et al., 1991; Serek, 1992; Serek and Andersen, 1993). A recent commercial replacement for STS treatment of cut flowers in Holland uses an inhibitor of ethylene biosynthesis as one of its important active ingredients (Harkema et al., 1991; Staden and Beekhuizen, 1986; Weltering et al., 1987). The most effective known inhibitor of ethylene biosynthesis is the bacterial toxin, rhizobitoxin, and its analog, aminoethoxyvinylglycine (AVG). AVG has been used successfully to increase the life of ethylene-sensitive cut flowers (Cook et al., 1985; Gladon and Spear, 1984; Spikman, 1989) held in air. In the presence of ethylene, AVG is likely to be less effective because it limits only ethylene biosynthesis, and does not prevent the action of external ethylene. Nell (1992) noted that a commercial product (Florish) containing an inhibitor of ethylene biosynthesis might be a valuable preservative for the cut flower industry, and expressed the possibility that similar anti-ethylene products will be developed for use on potted plants. Staby et al. (1993) found Florish to be of limited value for cut flowers exposed to ethylene. Because cut flower preservatives contain sugar, we could not test Florish itself for its effects on ethylene-sensitive potted plants. We therefore tested the effects of AVG, at concentrations that suppress the biosynthesis of ethylene, on the display life of Christmas cactus, a flowering potted plant, in air and in low-ethylene concentration. We selected the Christmas cactus because it is sensitive to ethylene (Cameron and Reid, 1981).

\section{Materials and Methods}

Christmas cactus plants in the tight-bud stage were obtained from a local nursery and transferred to a university greenhouse for the final production period. The conditions in the greenhouse were $20 \mathrm{C}$ day/night, $90 \%$ relative humidity (RH), and natural daylight. One week later the plants (in the balloon bud stage) were arranged in a randomized complete-block design, with 10-plant replications in each block. Treatments consisted of AVG at 10,30, or 100 $\mu \mathrm{M} ; 0.2 \mathrm{~mm}$ STS; or distilled deionized (DI) water. All treatment solutions, including the control (DI), contained $0.02 \%$ Triton X-100 as a surfactant. The plants were sprayed to runoff with $\approx 15 \mathrm{ml}$ of solution per plant.

\section{Results}

Effects of AVG on ethylene-induced bud abscission and plant longevity. When the oldest flowers had opened fully (7 days after AVG treatment), five plants of each treatment were placed in glass chambers, where they were exposed continuously to a flowing stream of air containing $1 \mu \mathrm{l}$ of ethylene/liter. Display life (number of days until the last flower on the plant wilted) and the time course of bud abscission were recorded. After 7 days of exposure to ethylene, the $100 \mu \mathrm{M}$ AVG-treated and control (DI) plants had lost $\approx 50 \%$ of their buds (Fig. 1). In contrast, plants pretreated with 0.2 mM STS still retained $>80 \%$ of their buds.

STS treatment was also effective in delaying flower wilting; thus, the display life of STS-treated plants was double that of control and AVG-treated plants at any of the AVG concentrations tested (Fig. 2).

Effects of AVG on postharvest characteristics in the interior environment (IE). The remaining plants were placed in the IE, where

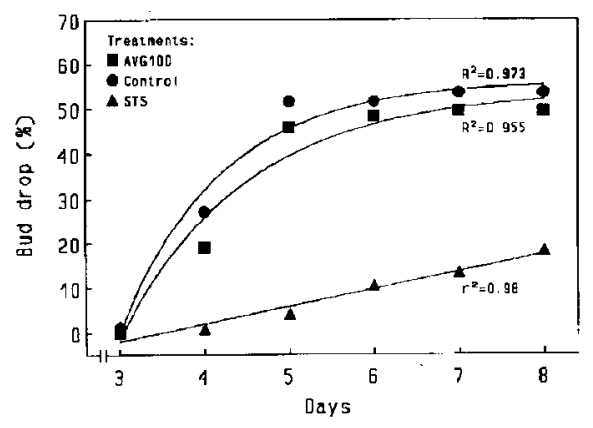

Fig. 1. Cumulative bud drop (percent) in S. truncata 'White Christmas' plants pretreated with 100 $\mu_{\mathrm{M}}$ of AVG/liter, $0.2 \mathrm{~mm}$ STS, or water (control). After treatment, plants were exposed to 1 $\mu \mathrm{l}$ of ethylene/liter for 8 days.

Source of variation:

Treatment

AVG vs. control

AVG vs. STS

STS vs. control

Days

Linear

Quadratic

Treatment $x$ days

AVG vs. control $\times$ linear

AVG vs. STS $\times$ linear

STS vs. control $\times$ linear

AVG vs. control $\times$ quadratic

AVG vs. STS $\times$ quadratic

STS vs. control $\times$ quadratic

мs,,$* * * *$ Nonsignificant or significant at $P \leq 0.01$ or 0.001 , respectively. 


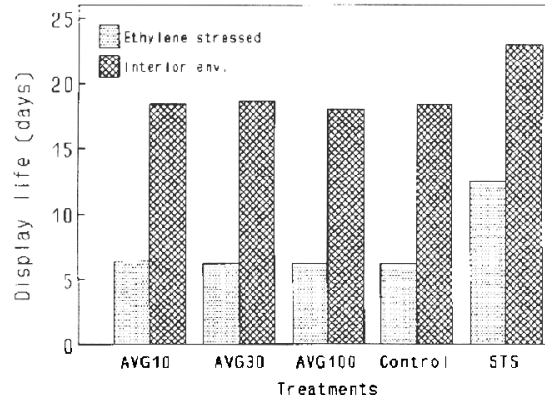

Fig. 2. Display life of $S$. truncata 'White Christmas' plants pretreated with various concentrations of AVG, 0.2 mm STS, or water (control). After treatment, plants were exposed to $1 \mu \mathrm{l}$ of ethylene/liter for 8 days or kept in a simulated interior environment until the last open flower had wilted. Source of variation:

Ethylene-stressed plants

AVG vs. control NS

AVG VS. STS ***

STS vs. control

Plants kept in interior environment

AVG vs. control NS

AVG VS. STS. *

STS vs. control *

ns,,$\cdots+$ Nonsignificant or significant at $P=0.05$ or 0.001 , respectively.

conditions were: $21 \mathrm{C}, 60 \% \mathrm{RH}$, and light (15 $\mu \mathrm{mol} \cdot \mathrm{m}^{-2} \cdot \mathrm{s}^{-1}$ ) for $12 \mathrm{~h} /$ day. Display life and bud abscission were recorded. After 19 days, AVG at $100 \mu \mathrm{m}$ had reduced cumulative bud drop by $\approx 20 \%$ (Fig. 3). In STS-treated plants, cumulative bud drop was only $50 \%$ of that in the control plants (Fig. 3). The AVG treatment had no significant effect on overall display life of the plants, but STS increased display life by 4 days (Fig. 2).

Effects of $A V G$ on ethylene biosynthesis. Control and AVG-treated (30pm) plants were kept in the IE described above for 16 days. Slices of the cladodes were placed inside 0.24 liter glass jars that were flushed with ethylenefree air and then sealed with a metal lid fitted with a serum cap, then held for $3 \mathrm{~h}$ at $20 \mathrm{C}$. A 3-ml aliquot of the air in the jar was then withdrawn for measurement of ethylene, using a gas chromatography fitted with a flame ionization detector (Carle AGC 111, Anaheim, Calif., and HNU PI-51, Newton, Mass.). Ethylene production by the AVG-treated tissues $[1.4 \mathrm{nl} / \mathrm{g}$ (fresh weight) per hour] was significantly lower $(P \leq 0.01)$ than that of control tissues $[2.6 \mathrm{nl} / \mathrm{g}$ (fresh weight) per hour].

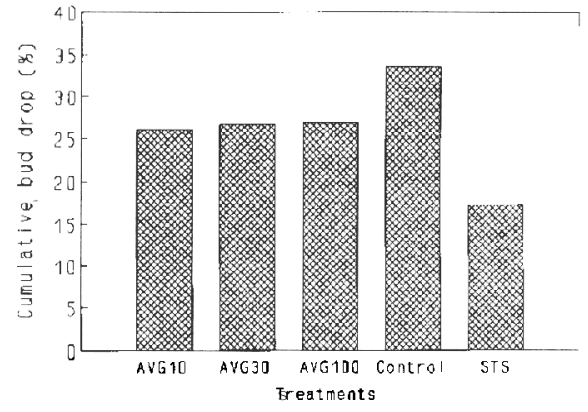

Fig. 3. Cumulative bud drop (percent) from $S$. truncata 'White Christmas' plants after 19 days in a simulated interior environment. Plants were treated with 10,30 , or $100 \mu \mathrm{M}$ of AVG/liter; 0.2 mM STS; or water (control) before placement in interior environments.

Source of variation:

Treatment

AVG vs. control *

AVG VS. STS ***

STS vs. control $* * *$

${ }^{* * s}$ Significant at $P=0.05$ or 0.001 , respectively.

\section{Discussion}

These data confirm the hypothesis that inhibitors of ethylene biosynthesis are of little benefit in improving the display life of plants subjected to external ethylene. Under the conditions of the experimental IE, we found some decrease in bud drop, indicating reduced stressethylene biosynthesis. Ethylene production by wounded cladodes was reduced significantly by AVG treatment. Reduction in endogenous production of ethylene maybe useful during marketing, when plants are frequently exposed to stressful circumstances. Because plants are, however, also frequently exposed to exogenous ethylene during marketing, pretreatment with STS or another inhibitor of ethylene action seems to be a better strategy. The environmental concerns related to STS use need to be addressed, first by care in application and disposal of used materials (Nell, 1992), and second by searching for effective alternatives, such as the volatile binding-site inhibitor reported by Sisler and Blankenship (1993), that can be registered for commercial use.

\section{Literature Cited}

Cameron, A.C. and M.S. Reid. 1981. The use of silver thiosulfate anionic complex as a foliar spray to prevent flower abscission of zygocactus. HortScience 16:761-762.
Cook, D., M. Rasche, and W. Eisinger. 1985. Regulation of ethylene biosynthesis and action in cut carnation flower senescence by cytokinins. J. Amer. Soc. Hort. Sci. 110:24-27.

Dostal, D.L., N.H. Agnew, R.J. Gladon, and J.L. Weigle. 1991. Ethylene, simulated shipping, STS and AOA affect corolla abscission of New Guinea impatiens. HortScience 26:47-49.

Fjeld, T. and R. Moe. 1985. Holdbarhetsmidler, spesielt sølvthio-sulfat (STS). Gartner Tidende 48:1580-1583.

Gladon, R.J. and G.J. Spear. 1984. Postshipment treatment of bud carnation with aminooxy-acetic acid, amino-ethoxy-vinyl-glycine, and silver thiosulfate. HortScience 19:567. (Abstr.)

Harkema, H., M.W.C. Dekker, and M.L. Essers. 1991. Distribution of amino-oxyacetic acid in cut carnation flowers after pretreatment. Scientia Hort. 47:347-353.

Nell, T.A. 1992. Taking silver safely out of longevity picture. Grower Talks June:35-38.

Nowak, J. and R.M. Rudnicki. 1990. Postharvest handling and storage of cut flowers, florist greens and potted plants. Chapman \& Hall, London.

Reid, M.S. 1985. Ethylene and abscission. HortScience 2045-50.

Reid, M.S. and M.J. Wu. 1992. Ethylene and flower senescence. Plant Growth Regulat. 11:3743.

Serek, M. 1992. Does salicylic acid affect the postharvest characteristics of Campanula catpatica? Gartenbauwissenschaft 57:112-114.

Serek, M. 1993. Ethephon and silver thiosulfate affect postharvest characteristics of Rosa hybrids 'Victory Parade'. HortScience 28:199-200.

Serek, M. and A.S. Andersen. 1993. AOA and BA influence on floral development and longevity of potted 'Victory Parade' miniature rose. HortScience 28:1039-1040.

Sisler, E.C. and S.M. Blankenship. 1993. Diazocyclopentadiene, a light sensitive reagent for ethylene receptor. Plant Growth Regulat. 12:125-132.

Spikman, G. 1989. Development and ethylene production of buds and florets of cut fresia inflorescences as influenced by silver thiosulfate, aminoethoxyvinylglycine and sucrose. Scientia Hort. 39:73-81.

Staby, G.L., R.M. Basel, M.S. Reid, and L.L. Dodge. 1993. Efficacies of commercial anti-ethylene products for fresh cut flowers. HortTechnology 3(2): 199-202.

Staden, O.L. and J.G. Beekhuizen. 1986. A new formula for the anti-ethylene pretreatment of cut carnation. Acts Hort. 181:425-427.

Veen, H. 1983. Silver thiosulfate: An experimental tool in plant science. Scientia Hort. 181:155160.

Veen, H. and S.C. van de Geijn. 1978. Mobility and ionic form of silver as related to longevity of cut carnations. Planta 140:93-96.

Woltering, E.J., H. Harkema, M.A. Maclaine Pent, and P.C.H. Hollman. 1987. Amino-oxyacetic acid: Analysis and toxicology. Acts Hort. 216:273-279 